\title{
Expression of Growth-Related Factors in Skeletal Muscle of Pirarucu (Arapaima Gigas) during Growth
}

Fernanda Regina Carani ${ }^{1 *}$, Bruno Oliveira da Silva Duran ${ }^{1}$, Warlen Pereira Piedade ${ }^{1}$, Fernanda Antunes Alves da Costa ${ }^{1}$, Vera Maria Fonseca de Almeida-Val ${ }^{2}$ and Maeli Dal-Pai-Silva ${ }^{1}$

${ }^{1}$ UNESP, Department of Morphology, Institute of Biosciences, 18618-970, Botucatu, SP, Brazil 2INPA, National Institute of Amazonian Research, 69060-001, Manaus, AM, Brazil

\begin{abstract}
The skeletal muscle of the species Arapaima gigas (pirarucu) constitutes the major edible part of the fish and is, therefore, an important protein source for human consumption. Post-natal muscle growth is regulated by the expression of myostatin as well as the Myogenic Regulatory Factors (MRFs) MyoD and myogenin. Once pirarucu reaches large size, we assume that the control of muscle growth by MRFs and myostatin occurs differentially at the initials life stages. In the present work we evaluated the morphological aspects and expression of MRF genes in skeletal muscle of pirarucu during early juvenile stage (Group A, up to $50 \mathrm{~g}, \mathrm{n}=7$ ), and post juvenile stages (Groups $B$, from 50 to $400 \mathrm{~g}, \mathrm{n}=7$; C, from $400 \mathrm{~g}$ to $5 \mathrm{~kg}, \mathrm{n}=7$, and $D$, from 5 to $9 \mathrm{~kg}, \mathrm{n}=7$ ). Transverse sections of red and white muscles were obtained to evaluate muscle fiber morphological and morphometric characteristics. MyoD, myogenin and myostatin genes and protein expressions were determined after quantitative real-time polymerase chain reaction and western blotting, respectively. Pirarucu skeletal muscle exhibited similar morphologies at different life stages. It was possible to conclude that both hyperplasia and hypertrophy occur during muscle growth in early and postjuvenile stages. As regard as expression, both mRNA and protein levels were similar among all groups for MyoD and myogenin. Myostatin presented lower mRNA levels and higher protein levels in early-juvenile stage, compared with the other groups. The levels of MRFs and myostatin might be involved in a balance that controls hyperplasia and hypertrophy occurring during post-natal muscle growth. Myostatin does not appear to play a crucial role during pirarucu early-juvenile stages. Since this species represents an interesting model for aquaculture programs due to high growing rates, our data suggest that the best phase to improve muscle growth in pirarucu is at post-juvenile stage and this will turn the employment of pirarucu farming economically better.
\end{abstract}

Keywords: Fish skeletal muscle; Muscle growth; 46 Myogenic regulatory factors; Myostatin; RT-qPCR; Western blotting; Pirarucu arapaima gigas

\section{Introduction}

Pirarucu (Arapaima gigas) is a member of the largest freshwater fish group in the world (the Teleosts) and is considered one of the most important species of the Amazonian ichthyofauna. The pirarucu fastgrowing characteristic allows it to reach up to $3 \mathrm{~m}$ length and $250 \mathrm{~kg}$ weight, when the 4 years-old pirarucu is called adult [1,2]. This species exhibits some intrinsic characteristics, such as rapid growth rates and rusticity, which enable it to be included in intensive rearing programs with excellent performance results. For this reason, it is important to investigate muscle growth mechanisms in this species. Skeletal muscle comprises the entire fillet in this fish species and lacks spines, one of the reasons it is widely appreciated as a food source for human $[3,4]$. Teleost fish skeletal muscle comprises around $60 \%$ of total body mass and is composed of different muscle fiber types organized in distinct areas [5]. The myotomes of adult fish contain a superficial lateral zone with red aerobic fibers, while the bulk of the musculature consists of white anaerobic fibers as described in [6]. Between the two layers, there is an intermediate layer of fibers with mixed characteristics related to metabolic and contractile activities [5,7-9]. During slow swimming speeds, as fish migrates, red muscle layers are the major active portion of muscle mass, whereas the white muscle is mostly recruited for bursts of rapid, vigorous activity $[8,10-12]$. The amount and arrangement of red and white muscle fibers, as well the red/white muscle ratio, can vary according to the fish species and swimming requirements, being an interesting characteristic regarding environmental adaptations [13].

Postnatal muscle growth in teleost fish involves the activation 71 and proliferation of a set of quiescent myogenic precursor cells, termed satellite cells, located at the periphery of the muscle fibers $[14,15]$. Their nuclei are absorbed by existing fibers as they expand in size (hypertrophy) or fuse together to form multinucleated myotubes and new fibers (hyperplasia). In fish, muscle grows continuously via hyperplasic and hypertrophic mechanisms throughout life [16,17]. These mechanisms are regulated by several types of transcriptional factors, which are muscle-specific, such as the Myogenic Regulatory Factors (MRFs), and by growth factors produced locally by muscle cells or neighbor tissues [18-21]. There are four MRFs described in the literature; MyoD, Myf5, myogenin and MRF4. MyoD and Myf5 are the first MRFs to be expressed in active satellite cells during post-natal period, regulating muscle fiber proliferation and, therefore, controlling hyperplasia. Myogenin and MRF4 roles are cell differentiation. They are also involved in hypertrophy, causing fiber maturation [21-25].

Another important regulator of skeletal muscle growth is Growth and Differentiation Factor 8 (GDF-8), widely known as myostatin. Myostatin is a member of the TGF- $\beta$ superfamily of proteins which

*Corresponding author: Fernanda Regina Carani, UNESP-Paulista State University, Department of Morphology, Institute of Biosciences, 18618-970 Botucatu, SP, Brazil, Tel: 5514 38800470; E-mail: fcarani@gmail.com

Received May 23, 2014; Accepted September 27, 2014; Published October 01, 2014

Citation: Carani FR, da Silva Duran BO, Piedade WP, da Costa FAA, de AlmeidaVal VMF, et al. (2014) Expression of Growth-Related Factors in Skeletal Muscle of Pirarucu (Arapaima Gigas) during Growth. J Aquac Res Development 5: 272. doi:10.4172/2155-9546.1000272

Copyright: (c) 2014 Carani FR, et al. This is an open-access article distributed under the terms of the Creative Commons Attribution License, which permits unrestricted use, distribution, and reproduction in any medium, provided the original author and source are credited. 
Citation: Carani FR, da Silva Duran BO, Piedade WP, da Costa FAA, de Almeida-Val VMF, et al. (2014) Expression of Growth-Related Factors in Skeletal Muscle of Pirarucu (Arapaima Gigas) during Growth. J Aquac Res Development 5: 272. doi:10.4172/2155-9546.1000272

Page 2 of 7

negatively regulates muscle growth, inhibiting both myoblast proliferation and differentiation [26-29]. It has been shown that the blockade of myostatin produces larger specimens of zebrafish (Danio rerio) and rainbow trout (Oncorhynchus mykiss), due to elevation of muscle hypertrophy and hyperplasia processes [30-33]. Myostatin has been isolated and characterized in several fish species [29,34-40]. In the present work, we have investigated the morphological characteristics and the expression of growth-related factors in skeletal muscle of pirarucu during growth. The results shown in the present study indicate that post-juvenile phase of pirarucu represents an interesting developmental stage for understanding 96 molecular mechanisms involved with muscle growth and our findings may help to improve the intensive rearing programs and production in fish farms.

\section{Materials and Methods}

\section{Sample collection}

This study was approved by the Biosciences Institute Ethics Committee of UNESP, Botucatu, SP, Brazil (Protocol N 72/07-CEEA). Pirarucu (Arapaima gigas) juvenile specimens were obtained from the Liberdade fish farm located in Uirapuru, GO, Brazil, and grouped according to their average body weight as follows: early juvenile stage (Group A, up to $50 \mathrm{~g}, \mathrm{n}=7$ ), and post juvenile stages (Groups B, from 50 to $400 \mathrm{~g}, \mathrm{n}=7$; C, from $400 \mathrm{~g}$ to $5 \mathrm{~kg}, \mathrm{n}=7$, and $\mathrm{D}$, from 5 to $9 \mathrm{~kg}, \mathrm{n}=7$ ). The animals were euthanized in a tank containing ice. Red and white muscle samples were obtained from superficial and deep lateral line regions of the fish, respectively; white muscle was also collected from the dorsal region. Both sampling areas were located close to the cranial region. The collected muscle samples were immediately frozen in liquid nitrogen and stored at $-80^{\circ} \mathrm{C}$.

\section{Morphological and morphometric analysis}

To evaluate morphological characteristics, transverse histological sections of red and white muscle samples ( $10 \mu \mathrm{m}$ thick) were obtained with a $-20^{\circ} \mathrm{C}$ cryostat microtome and stained with hematoxilin-eosin (HE) [41]. The smallest diameter of 200 white muscle fibers per animal were measured using a computerized image analyzer (DIGITAL IMAGE ANALYSIS SYSTEM QWIN V.3 FOR WINDOWS/LEICA, WETZLAR, GERMANY). We examined white muscle because it constitutes the prevailing part of the fish fillet. The muscle fibers were grouped into the following classes according to their diameter (adapted from [16] and [42]): class $10(<10 \mu \mathrm{m})$, class $20(\geq 10 \mu \mathrm{m},<20 \mu \mathrm{m})$, class $30(\geq 20 \mu \mathrm{m},<30 \mu \mathrm{m})$, class $50(\geq 30 \mu \mathrm{m},<50 \mu \mathrm{m})$, class $80(\geq 50$ $\mu \mathrm{m},<80 \mu \mathrm{m})$, and class $>80(\geq 80 \mu \mathrm{m})$ to evaluate the hyperplasic and hypertrophic white muscle growth rates.

\section{Gene expression analysis}

Total RNA isolation and reverse transcription: Total RNA was extracted from pirarucu white muscle tissue using the TRIZOL ${ }^{\circledR} 129$ reagent (INVITROGEN LIFE TECHNOLOGIES, CARLSBAD, CA, USA) following the manufacturer's protocol. The RNA samples were re-suspended in nuclease-free water and quantified by measuring the optical density (OD) at 260 and $280 \mathrm{~nm}$ using a NANOVUE ${ }^{\mathrm{nt}}$ PLUS SPECTROPHOTOMETER (GE HEALTHCARE, PISCATAWAY, NJ, USA). A $260 / 280 \mathrm{~nm}$ OD ratio $\geq 1.8$ was obtained to ensure high RNA purity, and RNA integrity was confirmed via electrophoresis on agarose gels. Total RNA was incubated with DNASE I AMPLIFICATION GRADE (INVITROGEN LIFE TECHNOLOGIES, CARLSBAD, CA, USA) to remove any residual genomic DNA present in the samples. Two micrograms of RNA were reverse transcribed using the HIGH CAPACITY cDNA ARCHIVE KIT (APPLIED BIOSYSTEMS, FOSTER
CITY, CA, EUA), as per the manufacturer's recommendations, and the final volume was adjusted to $100 \mu \mathrm{L}$ with RNase-free water.

Reverse Transcription-Polymerase Chain Reaction 143 (RTPCR), sequencing and sequence analysis: Complementary DNA (cDNA) was amplified using primer pairs designed based on the Ictalurus furcatus MyoD (Accession $\mathrm{N}^{\circ}$ AY562555), myogenin (Accession $\mathrm{N}^{\circ}$ AY540993) and myostatin (Accession $\mathrm{N}^{\circ}$ AY540992) gene sequences available in the GenBank database (http://www.ncbi. nlm.nih.gov). A set of primers designed based on the consensus fish $18 \mathrm{~S}$ ribosomal RNA sequence was used to amplify a segment of the $18 \mathrm{~S}$ rRNA gene in pirarucu muscle samples [43]. Each PCR assay consisted of $0.2 \mu \mathrm{g}$ of cDNA, $0.2 \mathrm{mM}$ of each primer and $22.5 \mu \mathrm{L}$ of PLATINUM $^{\circledR}$ PCR SUPERMIX (22 U/mL Platinum ${ }^{\circledR} 152$ Taq DNA Polymerase, $22 \mathrm{mM}$ Tris- $\mathrm{HCl} \mathrm{pH} 8.4,55 \mathrm{mM} \mathrm{KCl}, 1.65 \mathrm{mM} \mathrm{MgCl}$, $220 \mu \mathrm{M}$ dNTPs; LIFE TECHNOLOGIES, CARLSBAD, CA, USA) in a final volume of $25 \mu \mathrm{L}$. PCR amplifications were carried out with an initial denaturation step at $94^{\circ} \mathrm{C}$ for 2 minutes, followed by 35 cycles of $94^{\circ} \mathrm{C}$ for 1 minute, $55^{\circ} \mathrm{C}$ for 30 seconds and $72^{\circ} \mathrm{C}$ for 1.5 minutes, with a final extension step at $72^{\circ} \mathrm{C}$ for 5 minutes. The obtained PCR products were fractioned on $1.5 \%$ agarose gels, stained with GELRED ${ }^{\circ}$ (BIOTIUM, HAYWARD, CA, USA), and visualized under UV light using an image documentation system. The RT-PCR products were subjected to automated sequencing in an ABI 377 AUTOMATED DNA SEQUENCER (APPLIED BIOSYSTEMS, USA) using the BIGDYE $^{\circledR} 163$ TERMINATOR V.3.1 CYCLE SEQUENCING KIT (APPLIED BIOSYSTEMS, FOSTER CITY, CA, EUA) according to the manufacturer's instructions. Nucleic acid sequence database searches were performed using the BLAST tool [44] on the National Center for Biotechnology Information (NCBI) website (http://www.ncbi.nlm. nih.gov/blast). The partial MyoD, myogenin and myostatin mRNA 168 sequences, and the $18 \mathrm{~S}$ rRNA sequence, obtained from pirarucu skeletal muscle were used to design specific primers for quantitative PCR (real time PCR) analysis.

Quantitative PCR: Analyses of the expression of the MyoD, myogenin and myostatin genes were performed using the ABI 7300 REAL TIME PCR SYSTEM (APPLIED BIOSYSTEMS, FOSTER CITY, CA, EUA). Primers were designed with PRIMER EXPRESS ${ }^{\circ}$ 176 software (APPLIED BIOSYSTEMS, FOSTER CITY, CA, EUA) from pirarucu sequences obtained via RT-PCR. The primer sequences employed in these analyses were as follows: MyoD (forward) 5' CCA GCC CCA GGT CCA ACT, (reverse) 5' ACA CGT TGG GCC ATT GAA A; Myogenin (forward) 5’ AGG CTA CCC AAG GTG GAG ATC, (reverse) 5'TGC AGC CGC TCG ATG TAC T; Myostatin (forward) 5' CGA AGT ACA TGC ACC TGC AGA A, (reverse) 5' CGT GGG TTG GCC TTG TTT AC; and 18S rRNA (forward) 5' TAC CAC ATC CAA AGA AGG CAG, (reverse) 5' TCG ATC CCG AGA TCC AAC TAC. The $18 \mathrm{~S}$ rRNA gene was used as the reference gene in this study because it exhibits a similar level at each developmental stage analyzed. The PCR efficiencies for target and reference genes were evaluated based on seven serial dilutions (1:10) of sample cDNAs and showed an acceptable slope value of 188-3.32 [45]. Each qPCR amplification mixture contained $12.5 \mu \mathrm{L}$ of $2.5 \mathrm{X}$ POWER SYBR ${ }^{\circledR}$ GREEN PCR MASTER MIX (APPLIED BIOSYSTEMS, FOSTER CITY, CA, EUA), $40 \mathrm{ng}$ of cDNA $(20 \mathrm{ng} / \mu \mathrm{L}), 500 \mathrm{nM}$ of each primer and RNase-free water to a final volume of $25 \mu \mathrm{L}$. Amplifications were performed in duplicate with the following thermal cycling conditions: initial activation at $95^{\circ} \mathrm{C}$ for 10 minutes, followed by 40 cycles of $15 \mathrm{~s}$ at $95^{\circ} \mathrm{C}$ and 1 minute at $60^{\circ} \mathrm{C}$. The control reactions included a no template control (NTC) and a no reverse transcriptase control (-RT). Dissociation analysis of the PCR products was performed by running a gradient from $60^{\circ} \mathrm{C}$ to 
Citation: Carani FR, da Silva Duran BO, Piedade WP, da Costa FAA, de Almeida-Val VMF, et al. (2014) Expression of Growth-Related Factors in Skeletal Muscle of Pirarucu (Arapaima Gigas) during Growth. J Aquac Res Development 5: 272. doi:10.4172/2155-9546.1000272

Page 3 of 7

$95^{\circ} \mathrm{C}$ to confirm the presence of a single PCR product. The products were also sequenced to confirm their identity. The fluorescence signal baseline and threshold were set manually for each detector (for MyoD, myogenin, myostatin, and $18 \mathrm{~S}$ rRNA), generating a threshold cycle (Ct) for each sample. Sample quantification was accomplished via the comparative $\mathrm{Ct}$ method $(\Delta \Delta \mathrm{Ct})$, and the data are expressed as the fold-change in gene expression normalized to the reference gene and relative to the calibrator sample [46].

Protein expression analysis: The levels of the MyoD, myogenin and myostatin proteins in pirarucu white muscle were determined by western blotting using $\beta$-actin protein for normalization. Muscle samples were homogenized with IKA UltraTurrax/T-25 in lysis buffer ( $1 \%$ Triton X-100, $10 \mathrm{mM}$ sodium pyrophosphate, $100 \mathrm{mM} \mathrm{NaF}, 10 \mu \mathrm{g} /$ $\mathrm{mL}$ aprotinin, $1 \mathrm{mM}$ phenylmethylsulfonylfluoride (PMSF), $0.25 \mathrm{mM}$ $\mathrm{Na}_{3} \mathrm{VO}_{4}, 150 \mathrm{mM} \mathrm{NaCl}$, and $50 \mathrm{mM}$ Tris- $\mathrm{HCl}, \mathrm{pH}$ 7.5). The samples were centrifuged at $11,000 \times \mathrm{g}$ for $20 \mathrm{~min}$, and $50 \mu \mathrm{L}$ of the homogenate fraction was re-suspended in $25 \mu \mathrm{L}$ of Laemmli loading buffer (2\% SDS, $20 \%$ glycerol, $0.04 \mathrm{mg} / \mathrm{mL}$ bromophenol blue, $0.12 \mathrm{M}$ Tris- $\mathrm{HCl}, \mathrm{pH} 6.8$, and $0.28 \mathrm{M} \beta$-mercaptoethanol). Total protein was quantified based on Bradford method [46a] and $70 \mu \mathrm{g}$ was fractioned via one-dimensional SDS-PAGE (12\%). The proteins were then transferred from the gel to a nitrocellulose membrane. The membrane nonspecific binding sites were blocked using skim milk in Tris- $\mathrm{HCl}$ buffered saline containing Tween (TBS-T: $10 \mathrm{mM}$ Tris- $\mathrm{HCl} \mathrm{pH} 8.0,150 \mathrm{mM} \mathrm{NaCl}$, and $0.05 \%$ Tween-20), followed by primary antibody incubation 218 overnight at $4^{\circ} \mathrm{C}$ (MyoD M-318 sc-760; Myogenin M-225 sc-576; Myostatin C-20 sc6884 and $\beta$-actin R-22 sc-130657, SANTA CRUZ BIOTECHNOLOGY, CA, USA). After three steps of 10-minute washing with TBS-T buffer, membranes were incubated with horseradish peroxidase-conjugated secondary antibodies (goat anti-rabbit IgG-HRP sc-2004 and donkey anti-goat IgG-HRP sc-2020, SANTA CRUZ BIOTECHNOLOGY, CA, USA). Variations in the blocking solution concentration, blocking time duration, and primary and secondary antibody dilutions were determined according to each analyzed protein. Immunoreactive protein signals were detected using the SUPERSIGNAL WEST PICO CHEMILUMINESCENT SUBSTRATE KIT (THERMO FISHER SCIENTIFIC, ROCKFORD, IL, USA), according to the manufacturer's recommendations. The signals were captured on film, and the band intensities were quantified using densitometry analysis software (IMAGE J SOFTWARE FOR WINDOWS, VERSION 1.71, 2006, AUSTRIA).

Statistical analysis: The Goodman statistical test for multinomial proportions was used for analysis of the muscle fiber class distribution $[47,48]$. For gene and protein expression analysis, Kruskal-Wallis test was employed followed by Dunn multiple comparisons post-test to detect statistical significance. For all analysis, the results were considered significant at $95 \%$ of confidence interval $(\mathrm{p}<0.05)$. GraphPad InStat v. 3.01 software for Windows (1998, GRAPHPAD SOFTWARE, SAN DIEGO, CA, USA) was used.

\section{Results}

\section{Morphological analysis}

In all studied groups, red and white lateral muscles exhibited a similar morphological pattern. Muscle fibers presented normal features and were polygonal or round in shape, and multinucleated; nuclei were located at the periphery of the fibers. Fibers of different sizes were separated by a thin layer of connective tissue, endomysium. Groups of fibers were distributed in clusters separated by connective tissue, perimysium (Figure 1).

\section{Morphometric analysis}

Small-diameter fibers occurred between large ones, resulting in a variety of fibers with different diameters in white muscle (Figures $1 \mathrm{~B}$ and 1D). This pattern was observed both in dorsal and lateral musculatures. The distribution of muscle fibers followed an increase in diameter according to body weight, considering the predominant size. Early juvenile pirarucu (Group A) had most fibers in classes 20 and 30; post juveniles (Groups B, C and D) had fibers mostly between classes 50 and 80 (Figure 2).

\section{Gene expression analysis}

No statistical difference among groups were found for $18 \mathrm{~S}$ rRNA gene expression and it was used as reference to the other genes. MyoD, myogenin and myostatin transcript levels were quantitatively evaluated (RT-qPCR) and normalized based on $18 \mathrm{~S}$ rRNA transcript levels (Figure 3). No differences 266 were found between dorsal and deep lateral white muscles regarding to gene expression and both are referred in the text as white muscle.

Relative amounts of MyoD, myogenin, and myostatin transcripts in pirarucu white muscle are shown in Figure 3. No differences were found for the amplification of MyoD and myogenin mRNA among the

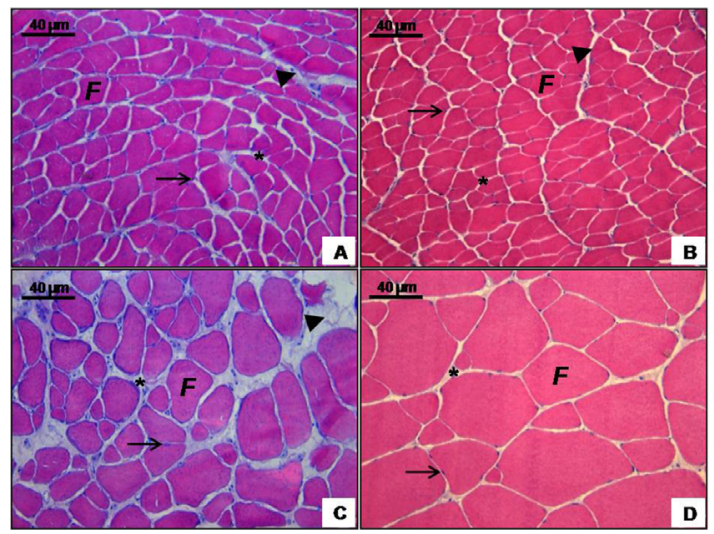

Figure 1: Histological sections of pirarucu (A. gigas) lateral skeletal muscle from group $A(A$ and $B)$ and group $C(C$ and $D)$. In $A$ and $C$ red muscle and in $B$ and $D$, whitemuscle. Polygonal or round muscle fibers $(F)$ surrounded by a thin connectivetissue, the endomysium $\left({ }^{*}\right)$. Note the perimysium (arrowhead) grouping musclefibers into fascicles. Nuclei (arrow) are in the peripheral location. HE stain (40X).

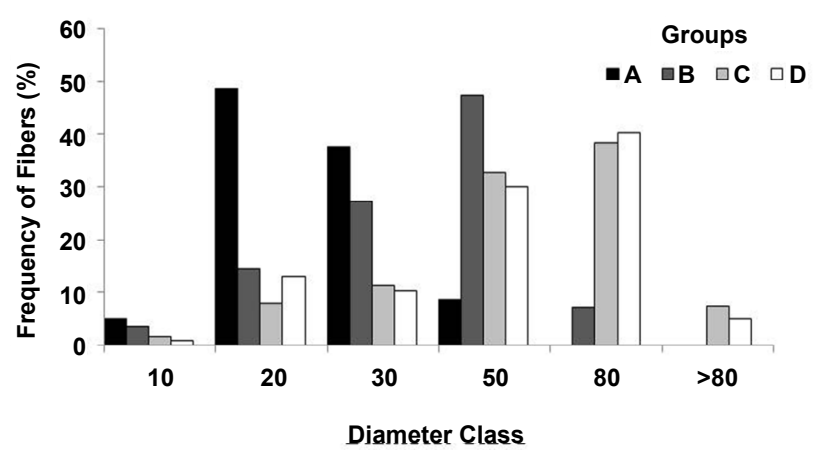

Figure 2: Frequency distribution of white muscle fibers in pirarucu (A. gigas), according to their diameter classes. Group A: up to $50 \mathrm{~g}$ weight, Group B: from 50to $400 \mathrm{~g}$ weight, Group C: from $400 \mathrm{~g}$ to $5 \mathrm{~kg}$ weight, Group D: from 5 to 9 $\mathrm{kg}$ weight. 


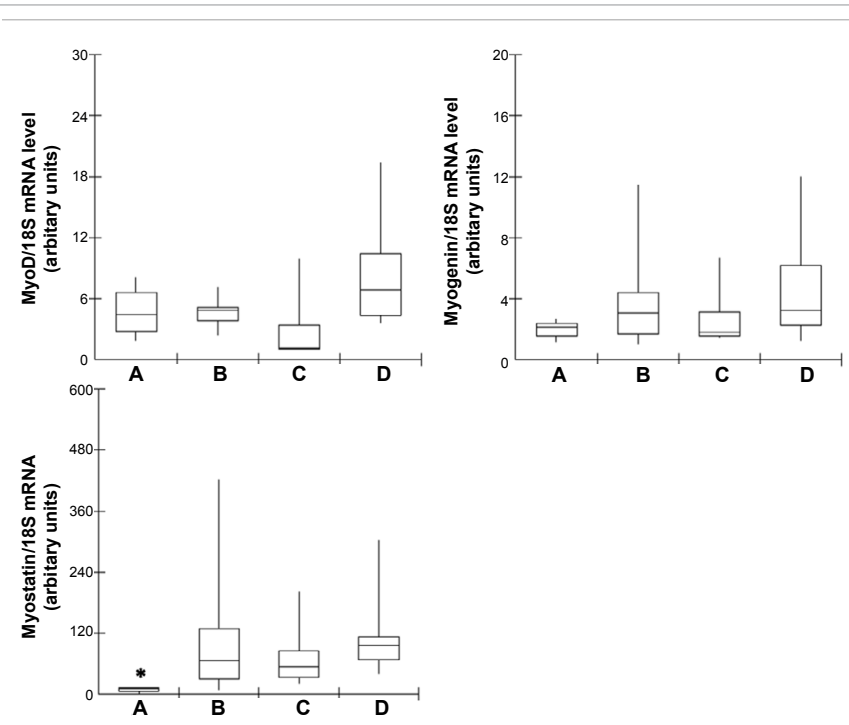

Figure 3: MyoD, myogenin and myostatin mRNA estimated levels in white skeletalmuscle of pirarucu (A. gigas) during growth. Data were normalized to 18Sribosomal RNA expression values. Data are presented as minimum, 1st quartile,median, 3rd quartile and maximum values. Group A: up to $50 \mathrm{~g}$ weight, Group B: from 50 to $400 \mathrm{~g}$ weight, Group C: from $400 \mathrm{~g}$ to $5 \mathrm{~kg}$ weight, Group D: from 5 to $9 \mathrm{~kg}$ weight. ( $\left.{ }^{*}\right)$ Statistical difference at $5 \%$ significance (Group A compared to $\mathrm{B}, \mathrm{C}$ and $\mathrm{D}$ ).
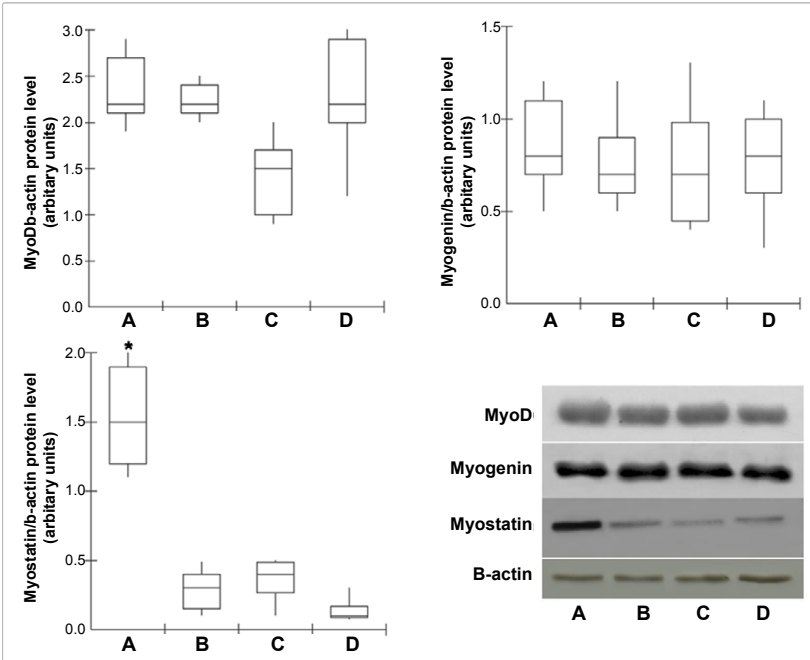

Figure 4: MyoD, Myogenin and Myostatin protein levels in white skeletal muscle ofpirarucu $(A$. gigas) during growth. Data were normalized to the $\beta$-actin proteinlevels. Data are expressed as minimum, $1^{\text {st }}$ quartile, median, $3^{\text {rd }}$ quartile andmaximum values. Group A: up to $50 \mathrm{~g}$ weight, Group B: from 50 to $400 \mathrm{~g}$ weight, Group C: from $400 \mathrm{~g}$ to $5 \mathrm{~kg}$ weight, Group D: from 5 to $9 \mathrm{~kg}$ weight. ${ }^{*}$ ) Statistical difference at $5 \%$ significance (Group A compared to B, C and D). Figure shows protein bands identified by chemiluminescent detection system.

studied groups ( $\mathrm{p}$ values: 0.2063 and 0.4533 , respectively), indicating that these genes contributed similarly during the whole period of growth from young to juveniles. In contrast, myostatin levels exhibited significant variation. The youngest group showed lower myostatin mRNA expression compared to groups B, C and D (p value: 0.0047 ), which levels were statistically similar.

\section{Protein expression analysis}

MyoD, myogenin and myostatin protein levels were normalized to $\beta$-actin. Muscle growth-related protein in the white muscle of pirarucu is shown in Figure 4. Similarly, MyoD and myogenin proteins contributed equally to all groups ( $p$ values: 0.999 and 0.392 , respectively). In contrast, myostatin exhibited higher levels in group A, compared to groups $\mathrm{B}, \mathrm{C}$ and $\mathrm{D}$ ( $\mathrm{p}$ value: 0.038 ).

\section{Discussion}

The present work is the first to describe the mechanisms regulating skeletal muscle growth in pirarucu (Arapaima gigas), which is a very important fish regarding economy of Amazon people. The organization of muscle fibers in pirarucu is quite similar to other fish species; red and white muscle fibers showed similar morphological patterns, presenting polygonal or round shapes with peripheral nuclei. Connective tissues of extracellular matrix are distributed in the endomysium, surrounding each muscle fiber, and in the perimysium, where muscle fibers are clustered [7,49-55]. The thick connective tissue found in dorsal muscle can be seen as a support structure for the whole body, allowing the transmission of contraction forces from muscle fibers to the axial skeleton and caudal fin. In all studied groups, analysis of white muscle fiber morphometry showed many small-diameter fibers surrounding larger fibers. This pattern is observed in most fish species during muscle growth and is characteristic of hypertrophy and hyperplasia $[12,17,55,56]$. In the majority of fish species, these mechanisms are employed throughout their life cycle and have been well documented in a variety of species, particularly in species with a large potential for aquaculture $[15,17,55,57]$. In the present work, we observed that early juvenile stage pirarucu (Group A) had many immature fibers, demonstrating that hyperplasia is probably the main muscle growth mechanism at that stage. This mechanism is responsible for the new fibers formation in fish species, once proliferative satellite cells aggregate to the mature fibers surface and generate new myotubes [15,58]. Post-juvenile fishes (groups B, C and D) also presented hyperplasia, identified by the occurrence of mosaic groups of fibers. However, they presented predominately larger fibers, what suggests hypertrophy as the main mechanism of muscle growth in these life stages. During this process, satellite cells fuse to pre-existing 313 fibers, increasing protein synthesis and resulting in larger fiber sizes [16,17]. Hypertrophy is, in fact, the main post-natal muscle growth mechanism during the juvenile and adult phases of most fish species $[59,60]$. Moreover, in larger fish species, it is well documented that hyperplasia predominates in early developmental stages but persists for a prolonged period during growth $[16,17,52,61,62]$. Pirarucu has the combination of both mechanisms (hyperplasia and hypertrophy) balanced during the different developmental stages, what explain its rapid growth rates observed in nature and aquaculture ponds (approximately $10 \mathrm{Kg}$ per year) [63-65]. Pirarucu grows up to $250 \mathrm{Kg}$, reaching $2 \mathrm{~m}$ long in nature. This is a remarkable growth for a scale freshwater fish, and it is associated with robust and continuous muscle development, which is under powerful machinery that contributes to the great increase in muscle mass during the early growth stages. In most fish, muscle thickening occurs via the apposition of muscle layers, a process known as stratified hyperplasia. The relative timing of this process in relation to the life cycle varies among fish species [16,42,66-68]. In large fish, it may predominate after hatching and persists during the early stages development. Therefore, based on our results, we suggest that stratified hyperplasia also contributes to a great increase in pirarucu's muscle mass. The expression of the MyoD and myogenin genes, as well as their related proteins in white muscle were not different among the several analyzed stages, which is consistent with many other studies [15$17,69,70]$ and may be attributed to the large requirement of fibers for 
muscle compartment thickening. This is a process that occurs rapidly in pirarucu, as it reaches a large size in a short period of time [63-65].

It is well known that hyperplasia depends on fish physiology 337 and lifestyle, and is mainly regulated by Myogenic Regulatory Factor MyoD, which is responsible for stimulating myoblast proliferation with subsequent formation of myotubes $[19,22,23]$. In this study, no difference was found in MyoD gene expression and protein concentration in differently sized fish. In this work, all groups showed intensive growth rates, as many of their fibers were newly formed. These findings suggest an atypical behavior for pirarucu muscle growth compared with other fish species [71-74], since all groups had similar characteristics of fish at initial stages, i.e., fast muscle growth $[3,4,70]$. As pirarucu achieves large size in the adult stage, the creation of many fibers during the first developmental stages is the best strategy to improve muscle growth. Myogenin regulates the late stages of muscle fiber formation and growth, which culminates in myoblast fusion, myotube formation, and adult muscle fiber differentiation [24,7577]. In the present study, neither the myogenin gene nor protein had different expression among the groups. These findings could be related to the intensive differentiation of muscle fibers, which occurs during all investigated growth stages. These fibers must fuse and form multinucleated myotubes that differentiate into muscle fibers, what is mainly regulated by myogenin [21,24,25]. Therefore, such similar myogenin expression levels found in pirarucu fibers may be attributed to the intensive rates of muscle fiber differentiation that occur regardless of fish size. One of the most important factors controlling skeletal muscle growth is myostatin. In the present work we described lower levels of myostatin transcripts in group A, compared to the higher levels in other groups. However, myostatin protein contents were higher in group A compared to other groups. Although there are few studies addressing the function of myostatin in fish, it is known that myostatin negatively regulates myoblast proliferation and differentiation $[28,29]$. The higher levels of myostatin mRNA in groups $\mathrm{B}, 362 \mathrm{C}$ and $\mathrm{D}$ indicate an intensive rate of gene transcription and this state may have been stimulated by low levels of myostatin protein in these groups, as demonstrated by protein analysis. Once myostatin was no more needed in higher groups, we suppose that the lack of a correlation between transcript and protein levels may be due to a negative feedback mechanism or post-transcriptional down regulation preventing myostatin protein formation. Once satellite cells are activated in these stages, it could be related to the intense muscle fiber formation. As myostatin pauses muscle growth when it appears at a low level, muscle fiber formation and differentiation are fully activated. During the posterior growth stages in pirarucu, myostatin exhibited low levels, indicating that the muscle differentiation rates had increased. Similar to myostatin results, the expression of MyoD and myogenin in pirarucu were associated with high proliferation and differentiation rates in bigger fish groups ( $\mathrm{B}, \mathrm{C}$ and $\mathrm{D})$, confirming the intense muscle differentiation in these groups. Several studies have attempted to describe the structure of the myostatin gene or simply determine its differential expression among distinct tissues [34,35,37,39,40,78]. There are few studies reporting myostatin levels during different fish growth phases [79]. Observed a low level of myostatin during the larval stage of zebrafish (Danio380 rerio), when hyperplasia is accentuated; in juvenile and adult phases, where muscle hyperplasic growth is less intense, myostatin expression was higher. These results do not agree with our findings, as this work has demonstrated intense muscle fiber recruitment during all the studied stages, although hypertrophy also occurred. During the early juvenile stages in pirarucu, although the level of myostatin mRNA was low, there was a high level of protein.
It was expected myostatin to be expressed at low levels throughout all evaluated growth stages. In this case, because the protein level was high during this period, it is possible that myostatin 387 may not be directly involved in negatively regulating muscle growth in pirarucu during the early juvenile growth stage. Similar to our results, showed that myostatin plays a dual role in regulating muscle growth at different developmental stages in medaka (Oryzias latipes) and regulates the number and size of fibers in a temporally controlled manner during post-hatch growth. Once myostatin effects on muscle growth in fish are not as well understood as in mammals, our results provided interesting insights to develop future experiments to better understanding the biological function of myostatin in skeletal muscle growth dynamics during early stage in fish.

In summary, our data suggest that MyoD, myogenin, and myostatin act to modulate the hyperplasic and hypertrophic muscle growth in pirarucu, which could be the major responsible for the outstanding growth performance observed in this species.

\section{Acknowledgment}

The authors thank Liberdade fish farming (Uirapuru, GO, Brazil), especially Gilberto Rabelo de Resende, for providing pirarucu specimens. This work was supported by grants from the FAPESP Foundation (Fundação de Amparo à Pesquisa do Estado de São Paulo-Process No 2007/59584-0 and 2007/588969) and CNPq Foundation (Conselho Nacional de Desenvolvimento Científico e Tecnológico-Process No 304070/2009-2 and 474084/2009-4).

\section{References}

1. Salvo-Souza R, Val AL (1990) O gigante das águas amazônicas. Ciência Hoje 11: $9-2$

2. Graham JB (1997) Air-Breathing Fishes; Evolution, Diversity and Adaptation Academic Press, San Diego, CA, USA.

3. Carvalho LODM, Nascimento CNB (1992) Fattening pirarucu (Arapaima gigas) in association with buffalo and pigs. Circular Técnica, EMBRAPA-CPATU, Belém, PA, Brasil.

4. Imbiriba EP (2001) Potencial de criação do pirarucu, Arapaima gigas, em cativeiro. Acta Amazonica 31: 299-316.

5. Sänger AM, Stoiber W (2001) Muscle fiber diversity and plasticity,Muscle development and growth. Academic Press, San Diego, CA, USA.

6. Hochachka PW, Guppy M, Guderley HE, Storey KB, Hulbert WC (1978) Metabolic biochemistry of water- vs. air-breathing fishes: muscle enzymes and ultrastructure. Can Jou Zool 56: 736-750.

7. Hoyle J, Gill HS, Weatherley AH (1986) Histochemical characterization of myotomal muscle in the grass pickrel, Esoxamericanus vermiculatus (LeSueur) and the muscle kellunge, E. masquinongy (Mitchill). Journal of Fish Biology 28 393-401.

8. Weatherley AH, Gill HS (1987) The biology of fish growth. Academic Press, London, UK.

9. Rescan PY (2005) Muscle growth patterns and regulation during fish ontogeny Gen Comp Endo 142: 111-116

10. Johnston IA, Davison W, Goldspink G (1977) Energy metabolism of carp swimming muscles. J Comp Physiol 114: 203-216.

11. Zhang G, Swank DM, Rome LC (1996) Quantitative distribution of muscle fiber types in the scup Stenoteomus chrysops. J Morphol 229: 71-81.

12. Johnston IA (1999) Muscle development and growth: potential implication for flesh quality in fish. Aquaculture 177: 99-115.

13. Almeida-Val VMF, Gomes ARC, Lopes NP (2005) Metabolic and physiological adjustments to low oxygen and high temperature in fishes of the Amazon, The Physiology of Tropical Fishes. Fish Physiology. Academic Press, San Diego, CA, USA.

14. Alfei L, Onali A, Spano L, Columbari PT, Altavista PL, et al. (1994) PCNA cyclin expression and BrdU uptake define proliferating myosatellite cells during hyperplastic muscle growth of fish (Cyprinus carpio L.). Eur J Histochem 38 151-162. 
Citation: Carani FR, da Silva Duran BO, Piedade WP, da Costa FAA, de Almeida-Val VMF, et al. (2014) Expression of Growth-Related Factors in Skeletal Muscle of Pirarucu (Arapaima Gigas) during Growth. J Aquac Res Development 5: 272. doi:10.4172/2155-9546.1000272

Page 6 of 7

15. Johnston IA, Alderson R, Sandham C, Dingwall A, Mitchell D, et al. (2000) Muscle fibre density in relation to colour and texture of smoked Atlantic salmon (Salmo salar L.). Aquaculture 189: 335-349.

16. Valente LMP, Rocha E, Gomes EFS, Silva MW, Oliveira MH, et al. (1999) Growth dynamics of white and red muscle fibres in fast- and slow-growing strains of rainbow trout. Journal of Fish Biology 55: 675-691.

17. Rowlerson A, Veggetti A (2001) Cellular Mechanisms of Post-Embryonic Muscle Growth in Aquaculture Species, in: Johnston IA (Ed.) Muscle development and growth. Fish Physiology. Academic Press, San Diego, CA, USA

18. Hawke TJ, Garry DJ (2001) Myogenic satellite cells: physiology to molecular biology. J Appl Physiol 91: 534-551.

19. Rescan PY (2001) Regulation and functions of myogenic regulatory factors in lower vertebrates. Comp Biochem B Physiol Biochem Mol Biol 130: 1-12.

20. Stamler JS, Meissner G (2001) Physiology of nitric oxide in skeletal muscle. Physioll Rev 81: 209-237.

21. Watabe $S$ (2001) Myogenic regulatory factors, Muscle development and growth. Fish Physiology. Academic Press, San Diego, CA, USA.

22. Goulding M, Lumsden A, Paquette AJ (1994) Regulation of Pax-3 expression in the dermomyotome and its role in muscle development. Development 120: 957-971.

23. Williams B, Ordahl CP (1994) Pax-3 expression in segmental mesoderm marks early stages in myogenic cell specification. Development 120: 785-796.

24. Megeney LA, Rudnicki MA (1995) Determination versus differentiation and the MyoD family of transcription factors. Biochem Cell Biol 73: 723-732.

25. Johansen KA, Overturf K (2005) Quantitative expression analysis of genes affecting muscle growth during development of rainbow trout (Oncorhynchus mykiss). Mar Biotech 7: 576-587.

26. McPherron AC, Lawler AM, Lee SJ (1997) Regulation of skeletal muscle mass in mice by a new TGF-beta superfamily member. Nature 387: 83-90.

27. Lee SJ, McPherron AC (1999) Myostatin and the control of skeletal muscle mass. Current Opinion in Genetics Dev 9: 604-607.

28. Thomas M, Langley B, Berry C, Sharma M, Kirk S, et al. (2000) Myostatin a negative regulator of muscle growth, functions by inhibiting myoblast proliferation. J Biol Chem 275: 40235-40243.

29. Langley B, Thomas M, Bishop A, Sharma M, Gilmour S, et al. (2002) Myostatin inhibits myoblast differentiation by down regulating MyoD expression. J Bio Chem 277: 49831-49840.

30. Acosta J, Carpio Y, Borroto I, Gonzalez O, Estrada MP (2005) Myostatin gene silenced by RNAi show a zebrafish giant phenotype. J Biotechnol 119: 324-331.

31. Rebhan Y, Funkenstein B (2008) Inhibition of fish myostatin 485 activity by recombinant fish follistatin and myostatin prodomain: Potential implications for enhancing muscle growth in farmed fish. Aquaculture 284: 231-238.

32. Lee CY, Lu JK, Wu JL (2009) Suppression of myostatin with vector-based RNA interference causes a double-muscle effect in transgenic zebrafish. Biochemical and Biophysical Research Communications 387: 766-771.

33. Medeiros EF, Phelps MP, Fuentes FD, Bradley TM (2009) Overexpression of follistatin in trout stimulates increased muscling. American Journal of Physiology -Regulatory, Integrative and Comparative Physiology 297: R235-R242.

34. Maccatrozzo L, Bargelloni L, Radaelli G, Mascarello F, Patarnello T (2001a) Characterization of the myostatin gene in the gilthead seabream (Sparus aurata): sequence, genomic structure, and expression pattern. Marine Biotechnology 3: 224-230.

35. Maccatrozzo L, Bargelloni L, Cardazzo B, Rizzo G, Patarnello T (2001b) A novel second myostatin gene is present in teleost fish. FEBS Letters 509: $36-$ 40.

36. Ostbye TK, Galloway TF, Nielsen C, Gabestad I, Bardal T, et al. (2001) The two myostatin genes of Atlantic salmon (Salmo salar) are expressed in a variety of tissues. Eur J Biochem 268: 5249-5257.

37. Rescan PY, Jutel I, Ralliere C (2001) Two myostatin genes are differentially expressed in myotomal muscles of the trout (Oncorhynchus mykiss). J Exp Biol 204: 3523-3529.

38. Roberts SB, Goetz FW (2001) Differential skeletal muscle expression of myostatin across teleost species, and the isolation of multiple myostatin isoforms. FEBS Letters 491: 212-216.

39. Rodgers BD, Weber GM, Sullivan CV, Levine 509 MA (2001) Isolation and characterization of myostatin complementary deoxyribonucleic acid clones from two commercially important fish: Oreochromis mossambicus and Morone chrysops. Endocrinology 142: 1412-1418.

40. Radaelli G, Rowlerson A, Mascarello F, Patruno M, Funkenstein B (2003) Myostatin precursor is present in several tissues in teleost fish: a comparative immunolocalization study. Cell and Tissue Res 311: 239-250.

41. Bancroft JD, Steven A (1990) Theory and Practice of Histological Techniques Churchill Livingstone, New York, USA

42. Veggetti A, Mascarello F, Scapolo PA (1990) Hiperplastic and hypertrophic growth of lateral muscle in Dicentrarchus labrax: an ultrastructural and morphometric study. Anat Embriol 182: 1-10.

43. Tom M, Chen N, Segev M, Herut B, Rinkevich B (2004) Quantifying fish metallothionein transcript by real time PCR for its utilization as an environmental biomarkers. Mar Pollut Bull 48: 705-710.

44. Altschul SF, Gish W, Miller W, Myers EW, Lipman DJ (1990) Basic local alignment search tool. J Mole Biol 215: 403-410.

45. Medhurst AD, Harrison DC, Read SJ, Campbell CA, Robbins MJ, et al. (2000) The use of TaqMan RT-PCR assays for semiquantitative analysis of gene expression in CNS tissues and disease models. J Neurosci Methods 98: 9-20.

46. Livak KJ, Schmittgen TD (2001) Analysis of Relative Gene Expression Data Using Real-Time Quantitative PCR and the 2- $\Delta \Delta$ Ct 530 Method. Methods 25 402-408.

47. Bradford MM (1976) A rapid and sensitive method for the quantification of microgram quantities of protein utilizing the principle of protein-dye binding. Ana Biochem 72: 248-254

48. Goodman LA (1964) Simultaneous confidence intervals for 534 contrasts among multinomial populations. Ann Math Statist 35: 716-725.

49. Goodman LA (1965) On simultaneous confidence intervals for multinomial proportions. Technometrics 7: 247-254

50. Alexander R (1969) The orientation of muscle in the myomers of fishes. Journal of the Marine Biological Association of the United Kingdom 49: 263-290.

51. Grizzle JM, Rogers WA (1979) Anatomy and histology of the channel cat fish University Agricultural Experiment Station, Opelika, Alabama, USA.

52. Dal Pai-Silva M, Dal Pai V, Mota DL, Rodrigues AC (1995) Histochemical study of muscle fiber types in Synbranchus marmoratus Boch, 1795. Ann Anat 177 65-70.

53. Dal Pai V, Dal Pai-Silva M, Carvalho ED, Fujihara CY, Gregorio EA et al. (2000) Morphological, histochemical and morphometric study of the myotomal muscle tissue of the pacu (Piaractus mesopotamicus Holmberg 1887: Serrasalminae, Characidae, Teleostei). Anat Histol Embryol 29: 283-289.

54. Fernandez DA, Calvo J, Franklin CE, Johnston IA (2000) Muscle fibre type and size distribuition in sub-antartic notothenoid fishes. J Fish Biol 56: 1295 1311.

55. Aguiar DH, Barros MM, Padovani CR, Pezzato LE, Dal Pai-Silva M (2005) Growth characteristics of skeletal muscle tissue in Oreochromis niloticus larvae fed on a lysine supplemented diet. J Fish Biol 67: 1-12.

56. Almeida FLA, Carvalho RF, Pinhal D, Padovani CR, Martins C, et al (2008) Differential expression of myogenic regulatory factor MyoD in pacu skeletal muscle (Piaractus mesopotamicus Holmberg 1887: Serrasalminae, Characidae, Teleostei) during juvenile and adult growth phases. Micron 39 1306-1311.

57. Veggetti A, Mascarello F, Scapolo PA, Rowlerson A, 559 Candia CMD (1993) Muscle growth and myosin isoform transitions during development of small teleost fish, Poecilia reticulata (Peters) (Atheriniformes, Poeciliidae): histochemical, immunohistochemical, ultrastructural and morphometric study. Anatomy and Embryology 187: 353-361.

58. Dal Pai-Silva M, Carvalho RF, Pellizzon CH, Dal Pai V (2003) Muscle fiber types in tilapia do Nilo (Oreochromis niloticus) from larval to adult: histochemical, ultrastructural and morphometric study. Tissue Cell 35: 179-187.

59. Rowlerson A, Mascarello F, Radaelli G, Veggetti A (1995) Differentiation and growth of muscle in the fish Sparus aurata (L): Il. Hyperplastic and hypertrophic 
Citation: Carani FR, da Silva Duran BO, Piedade WP, da Costa FAA, de Almeida-Val VMF, et al. (2014) Expression of Growth-Related Factors in Skeletal Muscle of Pirarucu (Arapaima Gigas) during Growth. J Aquac Res Development 5: 272. doi:10.4172/2155-9546.1000272

growth of lateral muscle from hatching to adult. J Muscle Res Cell Motil 16: 223-236.

60. Zimmerman AM, Lowery MS (1999) Hyperplastic Development and Hypertrophic Growth of Muscle Fibers in the White Sea bass (Atractoscion nobilis). J Exp Zoo 284: 299-308.

61. Weatherley AH, Gill HS, Lobo AF (1988) Recruitment and maximal diameter of axial muscle fibers in the teleosts and their relationship to somatic growth and ultimate size. J Fish Biol 33: 851-859.

62. Kiessling A, Storebakken T, Asgard T, Kiessling KH (1991) Changes in the structure and function of the epaxial muscle of rainbow trout (O. mykiss) in relation to ration and age. I. Growth dynamics. Aquaculture 93: 335-356.

63. Bard J, Imbiriba EP (1986) Piscicultura do pirarucu 584 (Arapaima gigas). Circular Técnica 52. EMBRAPA-CPATU, Belém, PA, Brasil.

64. Imbiriba EP, Lourenço-Júnior JB, Moura-Carvalho LOD, Goes LB, Uliana D, et al. (1996) Criação de Pirarucu. Empresa Brasileira de Pesquisa Agropecuária. Centro de Pesquisa Agroflorestal da Amazônia Oriental. Coleção Criar 2. EMBRAPA-SPI, Brasília, DF, Brasil.

65. Koumans JTM, Akster HA (1995) Myogenic cells in development and growth of fish. Comp Biochem Physi 110: 3-20.

66. Johnston IA, McLay HA (1997) Temperature and family effects on muscle cellularity at hatch and first feeding in Atlantic salmon (Salmo salar L.). Can Jou Zool 75: 64-74.

67. Johnston IA, Cole NJ (1998) Embryonic temperature modulates muscle growth characteristics in larval and juvenile herring (Clupea harehgus). J Exp Biol 201: 623-646.

68. Alami-Durante H, Fauconneau B, Rouel M, Escaffre AM, Bergot P (1997) Growth and multiplication of white skeletal muscle fibres in carp larvae in relation to growth rate. J Fish Bio 50: 1285-1302.

69. Assis JMF, Carvalho RF, Barbosa L, Agostinho CA, Dal-Pai-Silva M (2004) Effects of incubation temperature on muscle morphology and growth in pacu (Piaractus mesopotamicus). Aquaculture 237: 251-267.
70. Weinberg ES, Allende ML, Kelly CS, Abdelhamid A, Murakami T, et al. (1996) Developmental regulation of zebrafish MyoD in wild-type, no tail and spadetail embryos. Development 22: 271-280.

71. Delalande JM, Rescan PY (1999) Differential expression of two nonallelic MyoD genes in developing and adult myotomal musculature of the trout (Oncorhynchus mykiss). Deve Genes Evol 209: 432-437.

72. Tan X, Du SJ (2002) Differential expression of two MyoD genes in fast and slow muscles of gilthead seabream (Sparus aurata). Deve Genes Evol 212: 207-217.

73. Zhang Y, Tan X, Zhang P, Xu Y (2006) Characterization of Muscle-Regulatory Gene, MyoD, from Flounder (Paralichthys olivaceus) and Analysis of Its Expression Patterns During Embryogenesis. Mar Biotechnol 8: 139-148.

74. Decary S, Mouly V, Hamida CB, Sautet A, Barbet JP, et al. (1997) Replicative potential and telomere length in human skeletal muscle: implications for satellite cell-mediated gene therapy. Hum Gene Ther 8: 1429-1438.

75. Grobet L, Royo-Martin LJ, Poncelet DA (1997) Deletion in the bovine myostatin gene causes the double-muscled phenotype in cattle. Nat Gent 17: 71-74.

76. Schmalbruch $H$, Lewis DM (2000) Dynamics of nuclei of muscle fibers and connective tissue cells in normal and denervated rat muscles. Muscle Nerve 23: $617-626$.

77. Amali AA, Lin CJF, Chen YH, Wang WL, Gong HY, et al. (2004) Up-regulation of muscle-specific transcription factors during embryonic somitogenesis of zebrafish (Danio rerio) by knock-down of myostatin-1. Dev Dyn 229: 847-856.

78. Xu C, Wu G, Zohar Y, Du SJ (2003) Analysis of myostatin gene structure expression and function in zebrafish. J of Exp Bio 206: 4067-4079.

79. Chisada S, Okamoto H, Taniguchi Y, Kimori Y, Toyoda A, et al. (2011) Myostatindeficient medaka exhibit a double-muscling phenotype with hyperplasia and hypertrophy, which occur sequentially during post-hatch development. Dev Bio 359: 82-94. 